\title{
Effects of intravaginally inserted controlled-release dinoprostone and oxytocin for labor induction on umbilical cord blood gas parameters
}

\section{Doğum eylemi indüksiyonunda kullanulan intravajinal dinoproston ve oksitosin'in umblikal arter kan gazı parametreleri üzerine etkilerinin karşılaştırllması}

\author{
Hüseyin Levent Keskin, Gökalp Kabacaoğlu, Elçin İşlek Seçen, Işık Üstüner, Gülin Yeğin, Ayşe Filiz Avşar \\ Department of Obstetrics and Gynecology, Ankara Atatürk Education and Research Hospital, Ankara, Turkey
}

\section{Abstract}

Objective: To compare the effects of oxytocin and dinoprostone used in labor induction on fetal blood gas parameters.

Material and Methods: This prospective randomized trial involved 108 women who completed 37 gestational weeks and who required labor induction prior to normal vaginal birth. Labor was induced in 57 women with an intravenous low dose oxytocin regimen and in 51 with intravaginal dinoprostone $\left(\mathrm{PGE}_{2}\right)$. Following childbirth, umbilical artery blood gas was analyzed, with $\mathrm{pH}, \mathrm{pCO}_{2}, \mathrm{pO}_{2}, \mathrm{HCO}_{3}$ and base excess (BE) compared in the two groups.

Results: Mean age and obstetrical data (gravidity, parity, gestational weeks and birthweight) were similar in the two groups ( $p>0.05$ ). All infants had 1 and 5 minute APGAR scores $\geq 7$. Umbilical artery blood $\mathrm{pH}$ was similar in the oxytocin and dinoprostone groups $(7.31 \pm 0.07$ vs. $7.31 \pm 0.05, \mathrm{p}=0.780$ ), as were the other blood gas parameters ( $\mathrm{pCO}_{2}, \mathrm{pO}_{2}$, base excess and $\mathrm{HCO}_{3} ; \mathrm{p}>0.05$ each).

Conclusion: Induction of labor with either oxytocin or dinoprostone in women with uncomplicated term pregnancies had no adverse effects on umbilical artery blood gas parameters.

(J Turkish-German Gynecol Assoc 2012; 13: 257-60)

Key words: Oxytocin, dinoproston, umbilical artery blood gas, labor induction, $\mathrm{pH}$

Received: 13 August, 2012

Accepted: 18 November, 2012
Özet

Amaç: Bu çalışmada amacımız, doğum indüksiyonunda kullanılan iki metod olan oksitosin ve dinoprostonun fetal kan gazı parametreleri üzerine olan etkilerinin karşllaştırılmasıdır.

Gereç ve Yöntemler: Bu prospektif randomize çalışmaya 37 gebelik haftasını doldurmuş ve doğum eylemi indüksiyonu uygulanan ve vajinal yoldan doğumu gerçekleşen 108 olgu alındı. Eylem indüksiyonu için 57 olguya intravenöz yolla oksitosin, 51 olguya ise intravajinal dinoproston ( $\mathrm{PG} \mathrm{E}_{2}$ ) uygulandı. Doğumu takiben umblikal arter kan gazı analizi yapıldı ve her iki indüksiyon metodu için bazı parametreler $\left(\mathrm{pH}, \mathrm{pCO}_{2}, \mathrm{pO}_{2}, \mathrm{HCO}_{3}\right.$ and baz açığı (BE)) incelendi.

Bulgular: İki grup arasında ortalama yaş ve obstetrik değişkenler (gravida, parite, gebelik haftası ve doğum ağırlığı) benzer saptandı ( $>>0.05$ ). Tüm olgularda 1. ve 5. dakika Apgar skoru $\geq 7$ idi. Umbilikal arter kan $\mathrm{pH}$ değeri oksitosin grubunda $7.31 \pm 0.07$ iken ; dinoproston grubunda $7.31 \pm 0.05$ olarak izlendi $(\mathrm{p}=0.780)$. Diğer kan gazı parameterleri değerlendirildiğinde de $\left(\mathrm{pCO}_{2}, \mathrm{pO}_{2}\right.$, baz açığı ve $\left.\mathrm{HCO}_{3}\right)$ iki grup arasında belirgin farklılık saptanmadı $(\mathrm{p}>0.05)$.

Sonuç: Komplike olmayan term gebeliklerde doğum eylemi indüksiyonununda kullanılan iki metod olan oksitosin ve dinoprostonun fetal kan gazı parametreleri üzerine olumsuz etkisi yoktur.

(J Turkish-German Gynecol Assoc 2012; 13: 257-60)

Anahtar kelimeler: Oksitosin, dinoproston, umblikal arter kan gazı, doğum eylemi indüksiyonu, $\mathrm{pH}$

Geliş Tarihi: 13 Ağustos 2012

Kabul Tarihi: 18 Kasım 2012

\section{Introduction}

Induction of labor refers to the process whereby uterine contractions are initiated by mechanical or pharmacological methods before the onset of spontaneous labor (1). Induction of labor is advised in situations when the pregnancy is dangerous for the mother or fetus; or when induction is beneficial for both. Induction of labor decreases operative labor and minimizes risks to the fetus (2). Labor is induced in $20 \%$ of all pregnancies (3).
Among the factors influencing the method used to induce labor are cervical and membrane status, parity, and patient and provider preferences (4). The ideal method should be safe, painless, inexpensive, comfortable and effective. The most common pharmacological agents are oxytocin and prostaglandins ( $\mathrm{PGE}_{1}$ and $\mathrm{PGE}_{2}$ ) (5). Oxytocin is a safe and efficient starter of uterine contractions, but its success is associated with the condition of the cervix at the start of the labor. Dinoprostone $\left(\mathrm{PGE}_{2}\right)$ is used to turn an unfavorable to a favorable cervix before the induction of labor $(6,7)$.

Address for Correspondence: Elçin İşlek Seçen, Mutluköy Mah., Ağaçseven Sok., Elit Apt., No: 7, Ümitköy, Ankara, Turkey

Phone: +905067637903 e.mail: elcinislek@hotmail.com

(C) Copyright 2012 by the Turkish-German Gynecological Education and Research Foundation - Available online at www.jtgga.org doi:10.5152/jtgga.2012.41 
If labor is not induced under acceptable indications and surroundings, the uterus may be overstimulated, causing it to contract too frequently. Too many contractions may lead to changes in fetal heart rate and result in fetal distress (2). We therefore compared the effects of oxytocin and dinoprostone on fetal blood gas parameters.

\section{Material and Methods}

This study involved women pregnant for $\geq 37$ weeks who did not experience spontaneous uterine contractions, had a cervical Bishop score $\leq 3$, and were in need of labor induction. Women with fetal distress before labor induction, as determined by fetal monitoring; with a pathological umbilical artery or pathological findings on Doppler examination; with intrauterine growth retardation; or with maternal disease (e.g. thyroid dysfunction, diabetes, hypertension, preeclampsia, or cardiac disorders) were excluded. We enrolled 160 consecutive pregnant women fulfilling the above criteria; these women were randomized 1:1 to labor induction with oxytocin or dinoprostone using numbers generated randomly by a computer. Indications for labor induction were postterm pregnancy $(n=81)$, premature rupture of membranes $(n=50)$, non-assurance on non-stress tests $(n=11)$, and oligohydramnios (amniotic fluid index $<60 \mathrm{~mm}$ in all four quadrants; $n=18$ ). Seven women withdrew consent prior to the initiation of medication and were removed from the study.

Labor was induced in one group with intravenous low dose oxytocin (Synpitan ${ }^{\circledR}$ amp) and in the other with Propess ${ }^{\circledR}$, a hydrogel polymer matrix containing $10 \mathrm{mg}$ dinoprostone, administered intravaginally. Each woman in the oxytocin group received an intravenous infusion of $2 \mathrm{mU} / \mathrm{min}$ oxytocin, which was doubled at 15-min intervals until the appropriate contraction pattern (at least 200 Montevideo Units) was achieved. The infused dose was increased to a maximum of $20 \mathrm{mU} / \mathrm{min}$ and afterward kept constant, even after an ideal pattern was reached. If a contraction pattern had not been induced after 18 hours or if spontaneous labor did not start within 18 hours of receiving oxytocin, a cesarean section was performed.

In patients randomized to dinoprostone, fetal heart rate and uterine activity were monitored continuously, starting 15 to 30 minutes before treatment. A polymer matrix containing dinoprostone was placed intravaginally on the posterior fornix, releasing $\mathrm{PGE}_{2}$ at a constant rate of $0.3 \mathrm{mg} / \mathrm{h}$ over 12 hours. As hyperstimulation may occur after placement of the insert, fetal heart rate and uterine activity were monitored continually, from the time of insertion to 15 minutes after removal. The insert was removed by pulling the cord at the start of active labor or at the time of uterine hyperstimulation. If active labor did not start within 12 hours of insertion, the insert was removed and oxytocin infusion was begun.

Five patients in the dinoprostone group were removed from the study, 3 due to spontaneous dislocation of the insert and 2 due to hyperstimulation. Three patients in the oxytocin group elected to stop oxytocin infusion and were removed from the study. Eleven patients in the dinoprostone group were switched to oxytocin for progression of labor. An additional 11 patients were removed from the dinoprostone group, 6 for fetal distress and 5 for cephalopelvic disproportion and malpresentation; and 15 patients were removed from the oxytocin group, 7 for fetal distress, 5 for labor dystocia and 3 for non response to oxytocin. All 26 of these patients underwent cesarean sections. The remaining 108 patients, 51 in the dinoprostone group and 57 in the oxytocin group, were included in the study. The study flow chart is shown in Figure 1.

Following vaginal birth, the umbilical cord was clamped, and a 2 cc blood sample was drawn from the umbilical artery within 30 seconds. Blood gas samples were analyzed for $\mathrm{pH}, \mathrm{pCO}_{2}$, $\mathrm{pO}_{2}, \mathrm{HCO}_{3}$ and base excess (BE), while obeying the rules of cold chain. One and 5 minute APGAR scores of each newborn were recorded.

This study protocol was approved by the Local Ethics Committee of our Hospital, and all subjects provided informed consent.

\section{Power and Statistical Analyses}

The primary end point of our study was a comparison of blood gas parameters in the two groups. We calculated the minimal sample size for this trial using $\mathrm{G}^{*}$ power ver. 3.1.3 software (Germany). We estimated a minimum of 49 patients per group, assuming an effect size of 0.6 , a Type I error $(\alpha)$ of 0.05 and a statistical power of $90 \%$. Assuming an overall loss rate of $40 \%$, however, with $20 \%$ of patients undergoing cesarean section and $20 \%$ lost for other reasons, we planned to enroll 160 subjects (80 per group).

Data were analyzed using SPSS ver. 17.0 software. Before statistical analysis, the normal distribution of continuous data was tested using the Shapiro-Wilk test. All the parameters except for gravidity and parity were distributed normally $(p>0.05)$. Normally distributed parameters were expressed as mean \pm SD and compared using independent sample T tests, non-normally distributed parameters were expressed as median (IQR) and compared using Mann-Whitney $U$ tests. A p value $\leq 0.05$ was considered statistically significant.

\section{Results}

The mean age of all women enrolled in this study was $26.0 \pm 5.1$ years, and the mean gestational age was $39.8 \pm 1.0$ weeks.

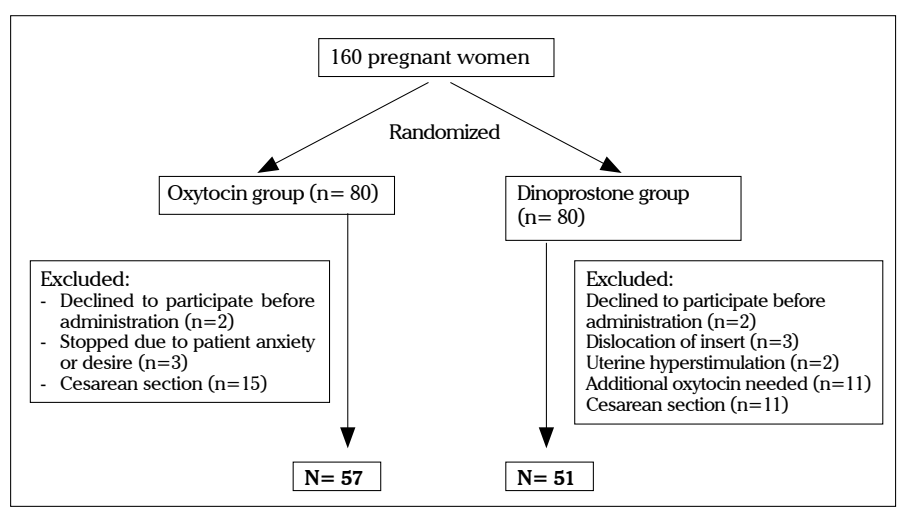

Figure 1. The flow chart of the study 
Indications for labor induction in the dinoprostone group included postterm pregnancy in 27 women, premature rupture of membranes in 18, oligohydramnios in 3 and non reassuring NST in 3; whereas indications in the oxytocin group were postterm pregnancy in 29, premature rupture of membranes in 22, oligohydramnios in 4 and non-reassuring NST in 2. The demographic and obstetrical data of the two groups were comparable ( $p>0.05$ each; Table 1). All infants had 1 and 5 minute Apgar scores $\geq 7$.

Comparisons of umbilical arterial blood gas $\mathrm{pH}, \mathrm{pCO}_{2}, \mathrm{pO}_{2}$, $\mathrm{HCO}_{3}$ and $\mathrm{BE}$ showed no differences between the oxytocin and dinoprostone groups ( $p>0.05$ each; Figure 2).

\section{Discussion}

The initiation of labor has become a routine procedure in gynecology and obstetrics clinics. Indications for labor induction include postterm pregnancy, early rupture of membranes, fetal distress, intrauterine growth restriction, fetal death, placenta detachment, preeclampsia, maternal disease and chorioamnionitis (2). We compared the effects of two different methods of labor induction on fetal blood gas parameters. To exclude the effects of fetal distress, we excluded women with chronic maternal disease, complications of pregnancy or fetal distress, and included only uncomplicated pregnancies ending with vaginal birth. Evaluations included Apgar scores and umbilical artery blood gas parameters of the newborn to determine whether acidemia had occurred.
Table 1. Demographic, clinical and blood gas characteristics in the ocytocin and dinoprostone groups

\begin{tabular}{|c|c|c|c|}
\hline & $\begin{array}{c}\text { Oxytocin } \\
(n=57)\end{array}$ & $\begin{array}{l}\text { Dinoprostone } \\
\quad(n=51)\end{array}$ & P value \\
\hline Age* & $\begin{array}{c}26.4 \pm 5.9 \\
(18-37)\end{array}$ & $\begin{array}{c}25.5 \pm 4.3 \\
(19-40)\end{array}$ & 0.576 \\
\hline Gravidity $\dagger$ & $\begin{array}{c}2.0(2) \\
(1-8)\end{array}$ & $\begin{array}{c}1.0(1) \\
(1-5)\end{array}$ & 0.034 \\
\hline Parity $\dagger$ & $\begin{array}{c}1.0(1) \\
(0-3)\end{array}$ & $\begin{array}{l}0(1) \\
(0-2)\end{array}$ & 0.195 \\
\hline Gestational weeks* & $\begin{array}{c}39.7 \pm 1.2 \\
(37.1-41.3)\end{array}$ & $\begin{array}{c}40.0 \pm 0.8 \\
(38.1-41.7)\end{array}$ & 0.469 \\
\hline Birthweight (g)* & $\begin{array}{c}3382 \pm 457 \\
(2555-4490)\end{array}$ & $\begin{array}{c}3473 \pm 385 \\
(2820-4320)\end{array}$ & 0.335 \\
\hline $\mathrm{pH}^{*}$ & $\begin{array}{l}7.31 \pm 0.07 \\
(7.10-7.47)\end{array}$ & $\begin{array}{l}7.31 \pm 0.05 \\
(7.18-7.38)\end{array}$ & 0.780 \\
\hline $\mathrm{pCO}_{2}(\mathrm{mmHg}) *$ & $\begin{array}{l}43.14 \pm 8.67 \\
(22.1-65.2)\end{array}$ & $\begin{array}{c}44.16 \pm 7.74 \\
(22.1-59.7)\end{array}$ & 0.579 \\
\hline $\mathrm{pO}_{2}(\mathrm{mmHg})^{*}$ & $\begin{array}{c}18.84 \pm 8.29 \\
(4.1-41.2)\end{array}$ & $\begin{array}{c}18.70 \pm 7.40 \\
(6.7-40.1)\end{array}$ & 0.981 \\
\hline $\mathrm{BE}(\mathrm{mmol} / \mathrm{L})^{*}$ & $\begin{array}{c}-3.76 \pm 2.50 \\
(-12-0)\end{array}$ & $\begin{array}{c}-3.28 \pm 2.92 \\
(-13-2)\end{array}$ & 0.479 \\
\hline $\mathrm{HCO}_{3}(\mathrm{mmol} / \mathrm{L})^{*}$ & $\begin{array}{c}21.71 \pm 1.19 \\
(19.8-25.6)\end{array}$ & $\begin{array}{c}21.86 \pm 1.68 \\
(19.2-25.4)\end{array}$ & 0.620 \\
\hline
\end{tabular}

*Mean \pm SD (min-max), $†$ Median (Interquartile range) (min-max)
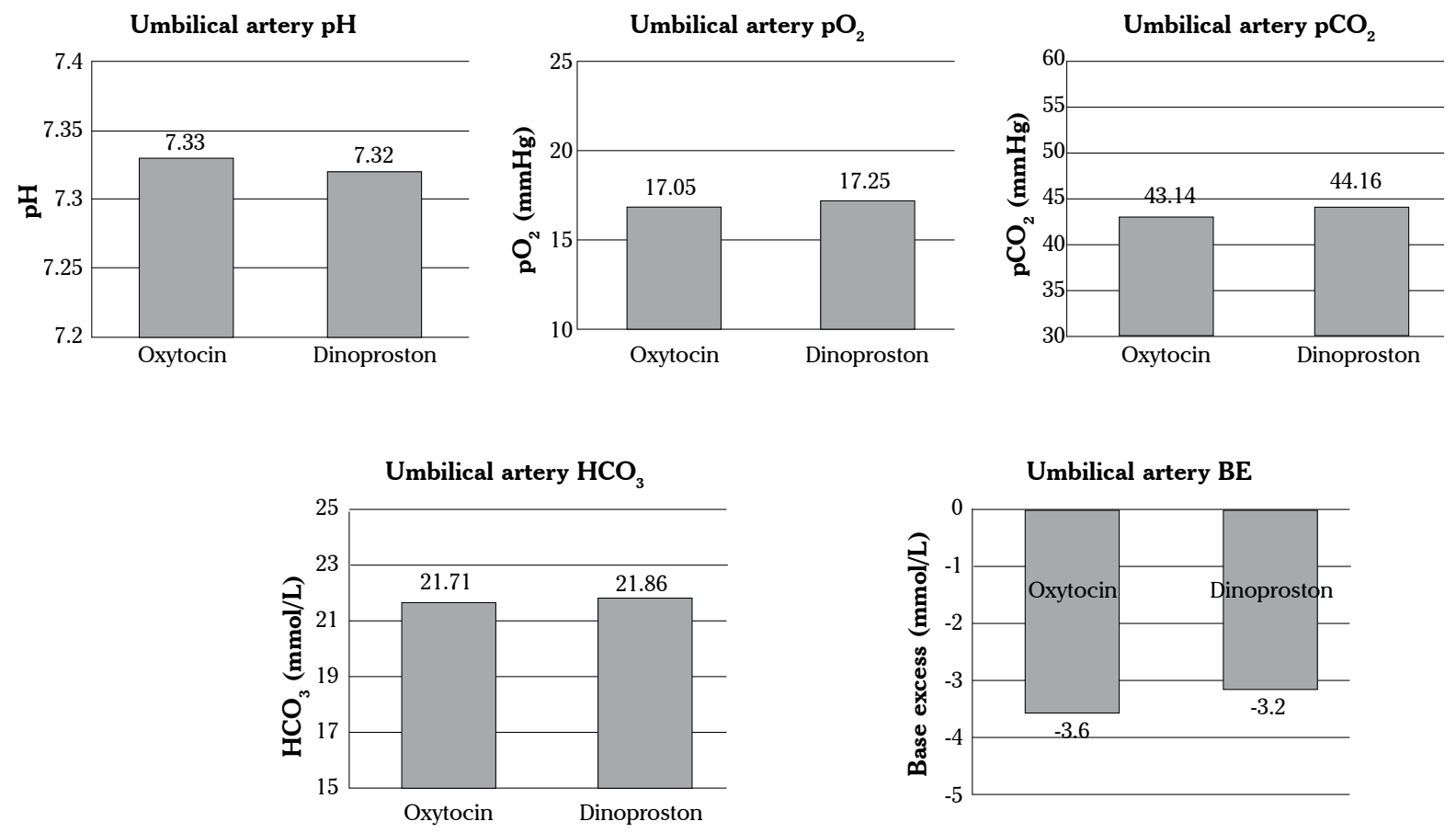

Figure 2. Umbilical artery blood gas parameters in the oxytocin and dinoprostone groups. (A) $\mathrm{pH},(\mathrm{B}) \mathrm{pO}_{2},(\mathrm{C}) \mathrm{HCO}_{3}$ concentration, (D) base excess (BE) 
Low Apgar scores are indications of fetal depression and hypotonicity and can be affected by many other parameters other than asphyxia. The acid/base status of umbilical artery blood gas may be an alternative to Apgar score in evaluating neonatal status and in managing any neonatal assistance required. Umbilical artery $\mathrm{pH}$ has been shown to be an objective measurement of fetal acid/base balance (8). Fetal acidemia has been defined as $\mathrm{pH} \leq 7.20$ and pathological fetal acidemia as $\mathrm{pH} \leq 7.0$. Risks of fetal morbidity and mortality were found to be increased at umbilical artery $\mathrm{pH} \leq 7.0$, whereas no morbidity was observed in term babies with umbilical artery $\mathrm{pH}>7.0$ (9). Intravenous administration of oxytocin is the method most frequently used to induce labor (10). Although treatment with oxytocin does not increase fetal morbidity, uterine hyperstimulation may result in fetal distress, uterine rupture and/or water intoxication (10). Uterine perfusion decreases during contractions, and increased uterine activity has negative effects on uteroplacental and fetoplacental circulation (11). Intravenous oxcytocin was shown to result in hyperstimulation in $8.3-11.1 \%$ of women and fetal distress in 15.9-18\%, suggesting that oxytocin application during labor may trigger fetal oxidative stress $(5,12)$. However, oxytocin did not have any negative effects on $\mathrm{pH}$ and did not increase perinatal risk $(11,13)$. When we investigated the effects of oxytocin-induced labor on fetal acid-base status, we observed an acid-base balance in the umbilical cord, a finding supported by intrapartum cardiotocographic findings and Apgar scores. Thus, the use of oxytocin to assist labor does not have negative effects on the fetus $(11,13)$.

Intracervical or intravaginal application of dinoprostone $\left(\mathrm{PGE}_{2}\right)$ is also frequently used to induce labor $(5,6,10)$. Long term treatment with low-dose controlled dinoprostone was well tolerated by both the mother and the fetus (14), with uterine hyperstimulation rates of $7.4-7.8 \%$ and fetal distress rates of $10.9-26 \%(5,12)$. In comparison, we observed lower uterine hyperstimulation $(2.6 \%)$ and fetal distress $(7.7 \%)$ rates in our dinoprostone group, whereas the fetal distress rate in our oxytocin group was $9.3 \%$. In addition, about $19 \%$ of women in whom cervical maturation was established with dinoprostone have been reported to require oxytocin for the progression of labor $(12,15)$. In comparison, we found that this rate was $14.1 \%$. Few studies to date have compared the effects of oxytocin and dinoprostone on fetal umbilical artery blood gas parameters. A comparison in 91 pregnant women showed no differences in methods of delivery or neonatal Apgar scores (16), although that umbilical artery blood $\mathrm{pH}$ was lower after $\mathrm{PGE}_{2}$ than after oxytocin treatment (16). Arterial and venous umbilical cord gas parameters have been found to be unaffected by oxytocin augmentation or induction $(11,13)$. Moreover Apgar scores, which indicate the well being of newborn infants, were shown to be statistically similar in women induced with dinoprostone and oxytocin $(5,12)$. We found that all Apgar scores were $\geq 7$, all umbilical artery pHs were above 7.10 , and none of the newborns experienced fetal acidosis. Umbilical artery blood gas parameters did not differ significantly in our oxytocin and dinoprostone groups, indicating that their safety and effectiveness were similar for labor induction.

\section{Conclusion}

We found that both labor induction agents, oxytocin and dinoprostone, did not have any unfavorable effects on fetal blood gas in uncomplicated term pregnancies.

\section{Conflict of interest}

No conflict of interest was declared by the authors.

\section{References}

1. Tenore JL. Methods for cervical ripening and induction of labor. Am Fam Physician 2003; 67: 2123-8.

2. ACOG practice bulletin. Induction of labor. Number:10, November 1999 (Replaces technical bulletin No:217, December 1995). Obstet Gynecol Reproduction 1999; 94: 1-10.

3. Mackenzie IZ. Induction of labour at the start of the new millennium. Reproduction 2006; 131: 989-98. [CrossRef]

4. Mozurkewich EL, Chilimigras JL, Berman DR, Perni UC, Romero VC, King VJ, et al. Methods of induction of labour: a systematic review. BMC Pregnancy Childbirth 2011; 11: 84. [CrossRef]

5. Akay NÖ, Hızlı D, Yılmaz SS, Yalvac S, Kandemir O. Comparison of low-dose oxytocin and dinoprostone for labor induction in postterm pregnancies: a randomized controlled prospective study. Gynecol Obstet Invest 2012; 73: 242-7. [CrossRef]

6. Christensen FC, Tehranifar M, Gonzalez JL, Qualls CR, Rappaport VJ, Rayburn WF. Randomized trial of concurrent oxytocin with a sustained-release dinoprostone vaginal insert for labor induction at term. Am J Obstet Gynecol 2002; 186: 61-5. [CrossRef]

7. Hadi H. Cervical ripening and labor induction: clinical guidelines. Clin Obstet Gynecol 2000; 43: 524-36. [CrossRef]

8. Thorp JA, Dildy GA, Yeomans ER, Meyer BA, Parisi VM. Umbilical cord blood gas analysis at delivery. Am J Obstet Gynecol 1996; 175: 517-22. [CrossRef]

9. Gordon A, Johnson JW. Value of umbilical blood acid-base studies in fetal assessment. J Reprod Med 1985; 30: 329-36.

10. Dündar Ö, Tütüncü L, Ergür AR, Atasever B, Müngen E. Comparison of Intravaginal misoprostol, oxytocin infusion and intracervical dinoprostone, oxytocin infusion in postterm pregnancies for labor induction. Turkiye Klinikleri J Gynecol Obst 2008; 18: 231-6.

11. Loghis C, Salamalekis E, Vitoratos N, Panayotopoulos N, Kassanos D. Umbilical cord blood gas analysis in augmented labour. J Obstet Gynaecol 1999; 19: 38-40. [CrossRef]

12. Yılmaz B, Güngör T, Bilge U, Onen S, Ozaksit G, Sut N, et al. Randomized comparison of sustained-release dinoprostone vaginal insert versus oxytocin for cervical priming/labor induction in post-term pregnants with unfavorable cervix. Turkiye Klinikleri J Gynecol Obst 2008; 18: 237-42.

13. Thorp JA, Boylan PC, Parisi VM, Heslin EP. Effects of high-dose oxytocin augmentation on umbilical cord blood gas values in primigravid women. Am J Obstet Gynecol 1988; 159: 670-5.

14. Yogev Y, Ben-Haroush AB, Gilboa Y, Chen R, Kaplan B, Hod M. Induction of labor with vaginal prostaglandin E2. J Matern Fetal Neonatal Med 2003; 14: 30-4. [CrossRef]

15. Paliwal V, Dikhit S, Singh S. Safety of induction of labor with vaginal prostaglandins (E2) in grandmultipara. Oman Med J 2009; 24 : 184-7.

16. Lyndrup J, Legarth J, Dahl C, Philipsen T, Eriksen PS, Weber T. Induction of labour: the effect of vaginal prostaglandin or i.v. oxytocin--a matter of time only? Eur J Obstet Gynecol Reprod Biol 1990; 37: 111-9. [CrossRef] 